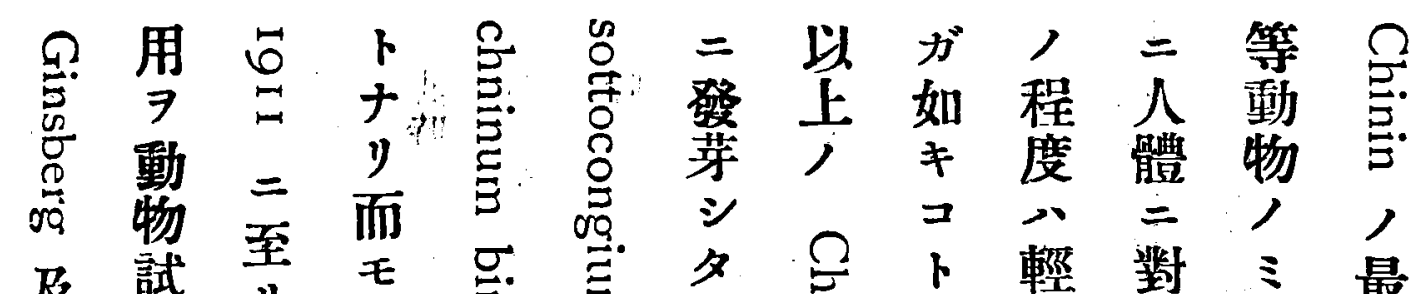

及試至 毛 号奇 タ

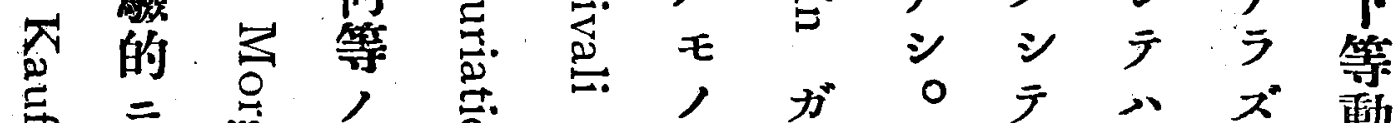

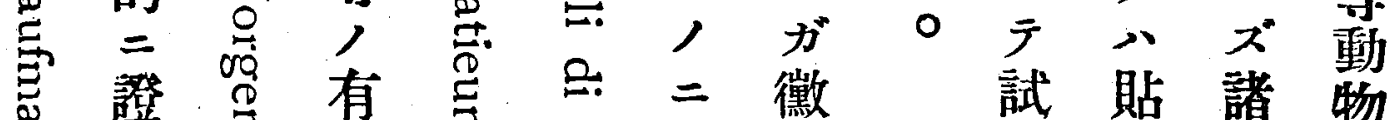

證高害 $\Xi$ 有徽 試貼諸物

吉明害害 $气$ 导 シ 菌 = 用, 種 殊

亦具 号 作 9 点

家 且用 以

兔本 7 テ 0 这

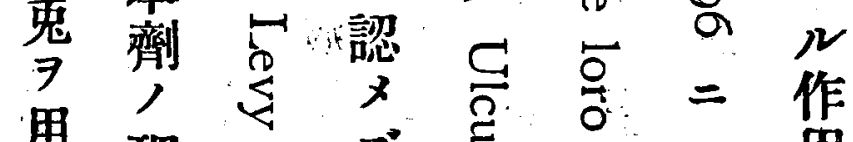

用理

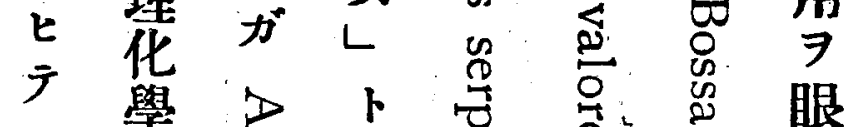

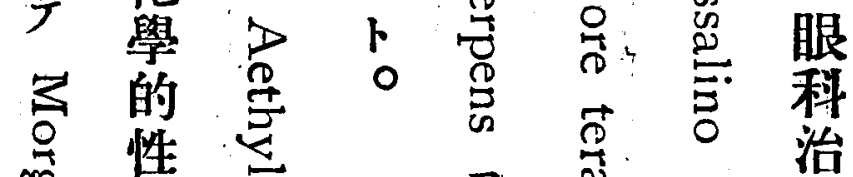

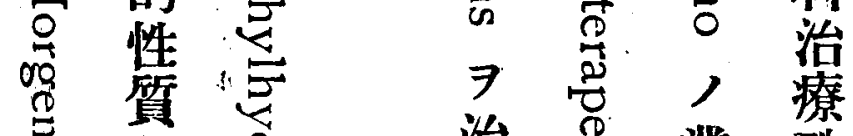

吉学 治 总 業 殊

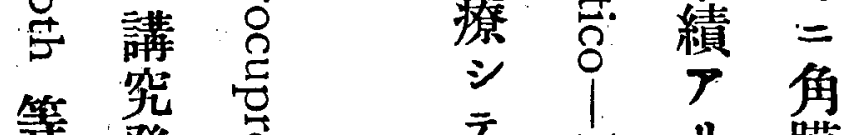

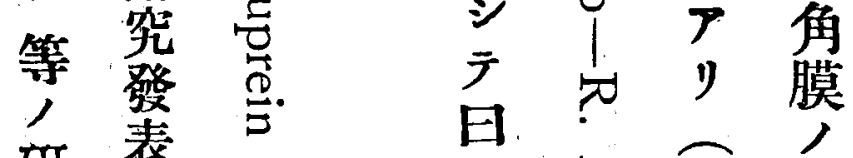

研表它

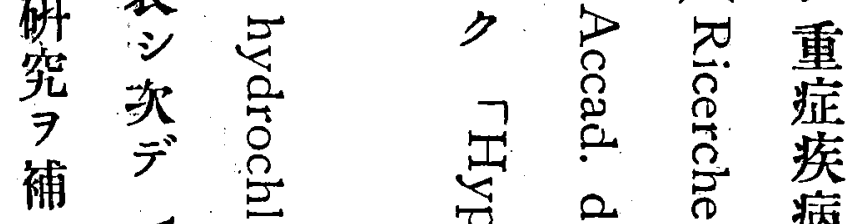

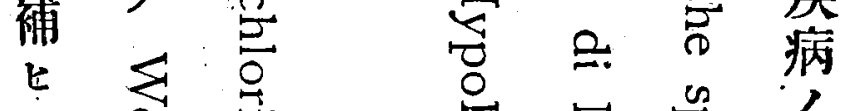

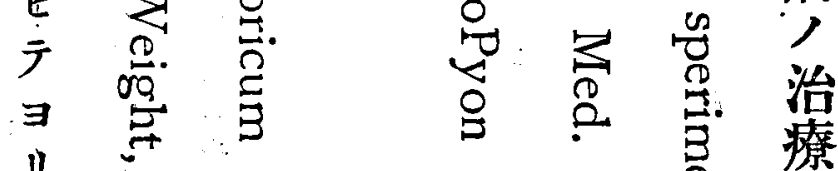

1)

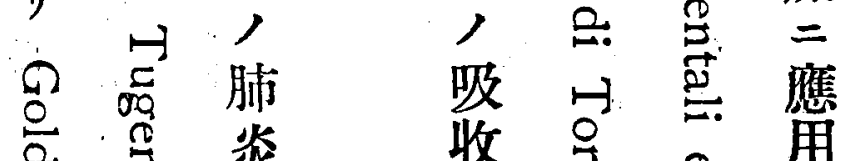

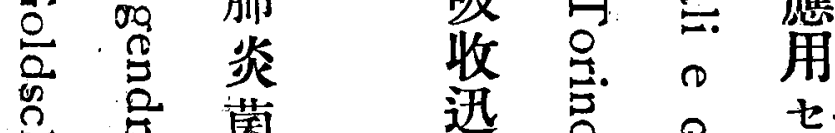

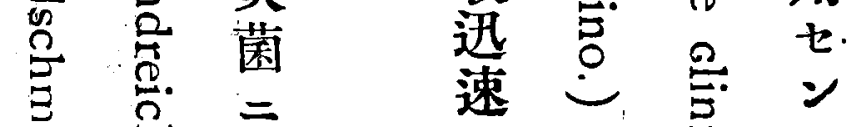

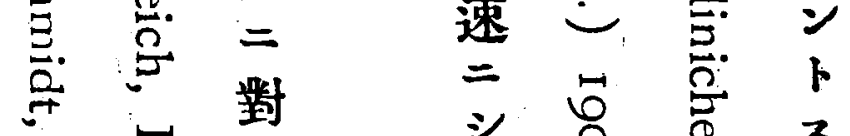

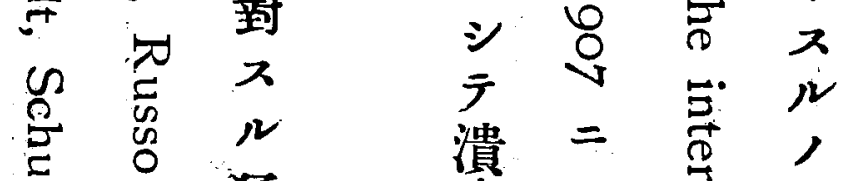

等 等 猛 溃

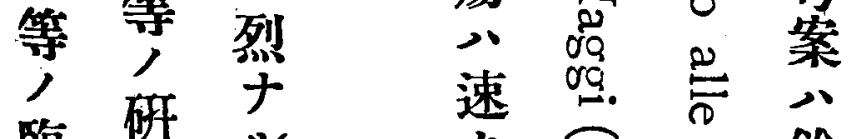

臨究研学守吉餘

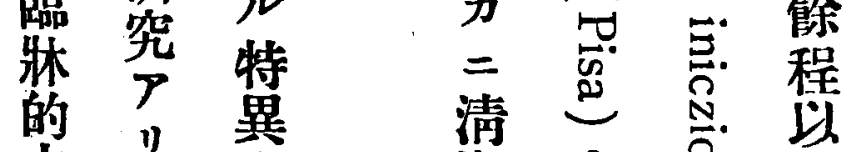

方り作 潔 亦巷 前

人菌点

溶 タ

液 ル 對 氞.

$\Rightarrow$ 局 吾

點 所 广

眼 7 モ

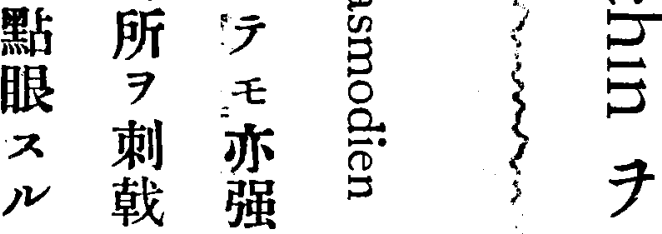

卜 $シ$ 烈 $=$

キ テ = 對

八其 作

転 細 用 猛

$\neq$ 胞 $三 ，$ 烈

結 $尹$ 其

膜 死 三

充 隇 作

血 $七$ 用

$\Rightarrow$ シ $\%$

起メ> 呈

以

シ $ン$ 溶

灼占液光

熱 シ 中

感 其 $=$ r

马部 於 八

訴 $=\bar{F}$

7 炎 》

2 症 既人

外 $\rightarrow=$,

著 起 發 知

流年

疼 然停

七

ル

痛 ド止り一

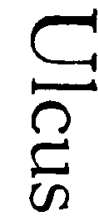

$\exists$ Z

發基。 需

又刺 0

韩更下 
九

百

山製 ト

所 劑 $\stackrel{7}{7}$ 咅

謂 通 盟 8

○有七,

号 性 ラ 溶

壱 シ タ 液

7 涌? 短

以 通副時

三 常 副 間

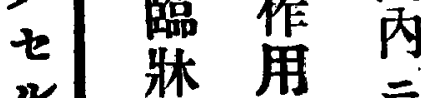

的占 二

员 角

七

今 前 撲

記 殺力而數李 7 本橉 、

治

品 二 此 广本 $尹$ 亦 0 总 濃年用驗 品出

度 浮 八管 徽 ズ

郎腫呙菌次

キ人 号二就 デ

三 外 輕 㝕 於 中 $气$ 如

以 ₹

下 腐 $\ddot{\circ}$ 菌

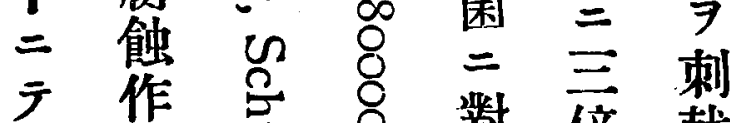

八角壳 8 對倍戟

左了其, 㳊及

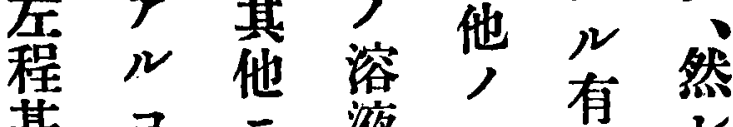

甚 $=$ 液

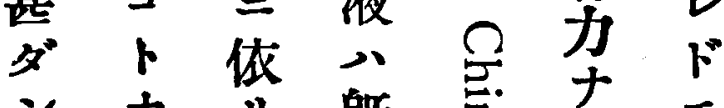

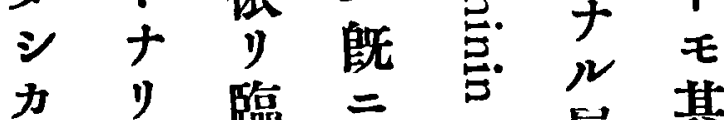

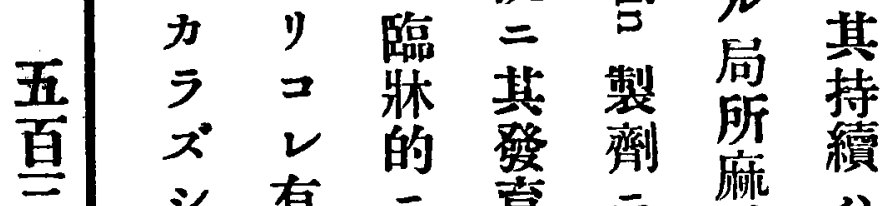

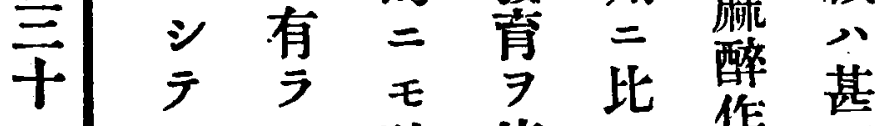

一カ工確停势㤰甚

$ノ ル$ 實步著用短

銀○ナセ齐發》

點 家 ル シ ク發 シ

眼导コメ有 ス
應 所 國 科 面

二謂 二 治 =

于。於療於

八骂界界

直员小,

于 它 未 泩 報

ニ ダ.意 告

溶

液》》若り

$\exists$ 吕一ク諸

り安般二方

白要臨 至 面

色气牀 $v=$

啐官家り於

狀 吉二、午

三 試 然

析 刍

出, セド會

品師

志、酸ル本於

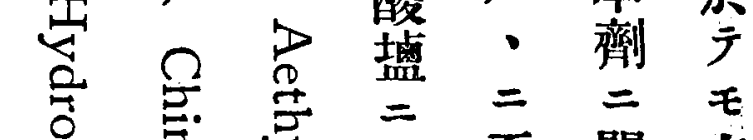

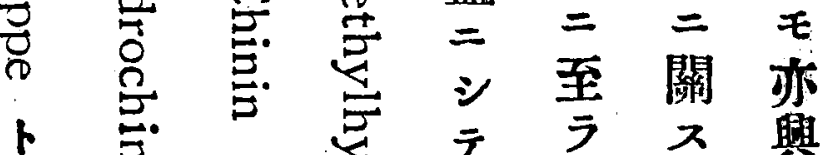

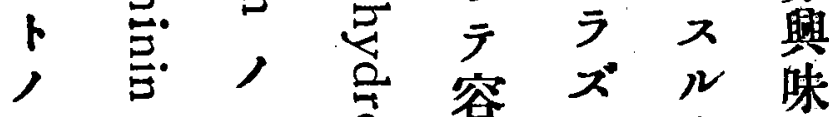

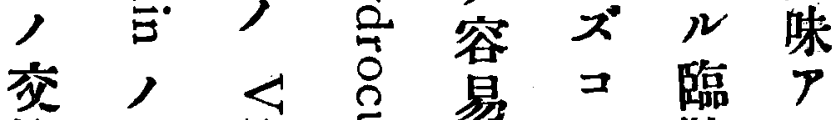
換 $气$ 志易 $匚$ 躁

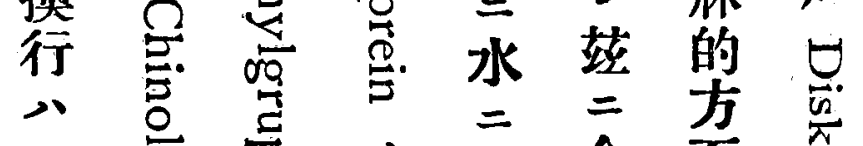

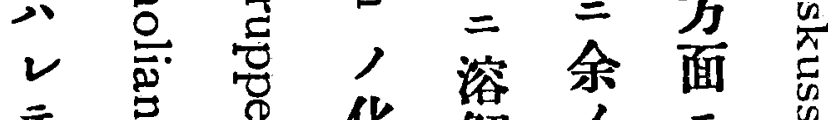

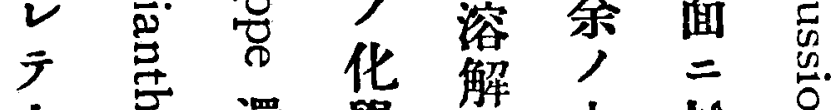
上還學不小於号 記三元的少實尔㝵 人

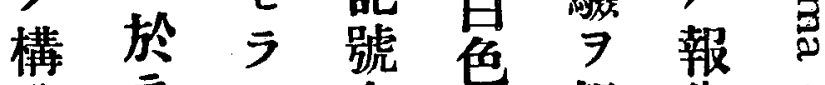
造 テ レ次粉報告ト $\exists \gg$ 万告心 有总声如狀七监亏

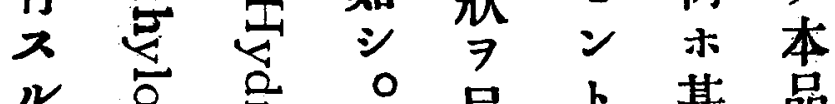
它齐 ○呈卜甚品

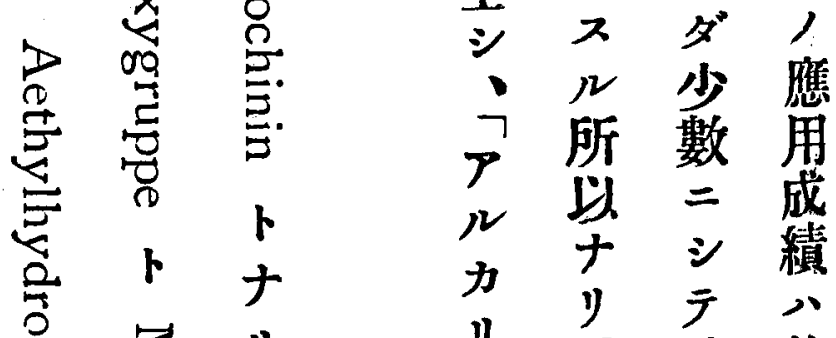

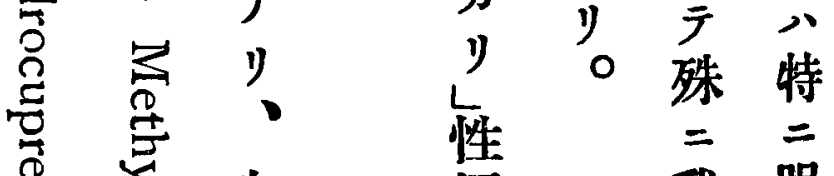
兽安次年 我眼 


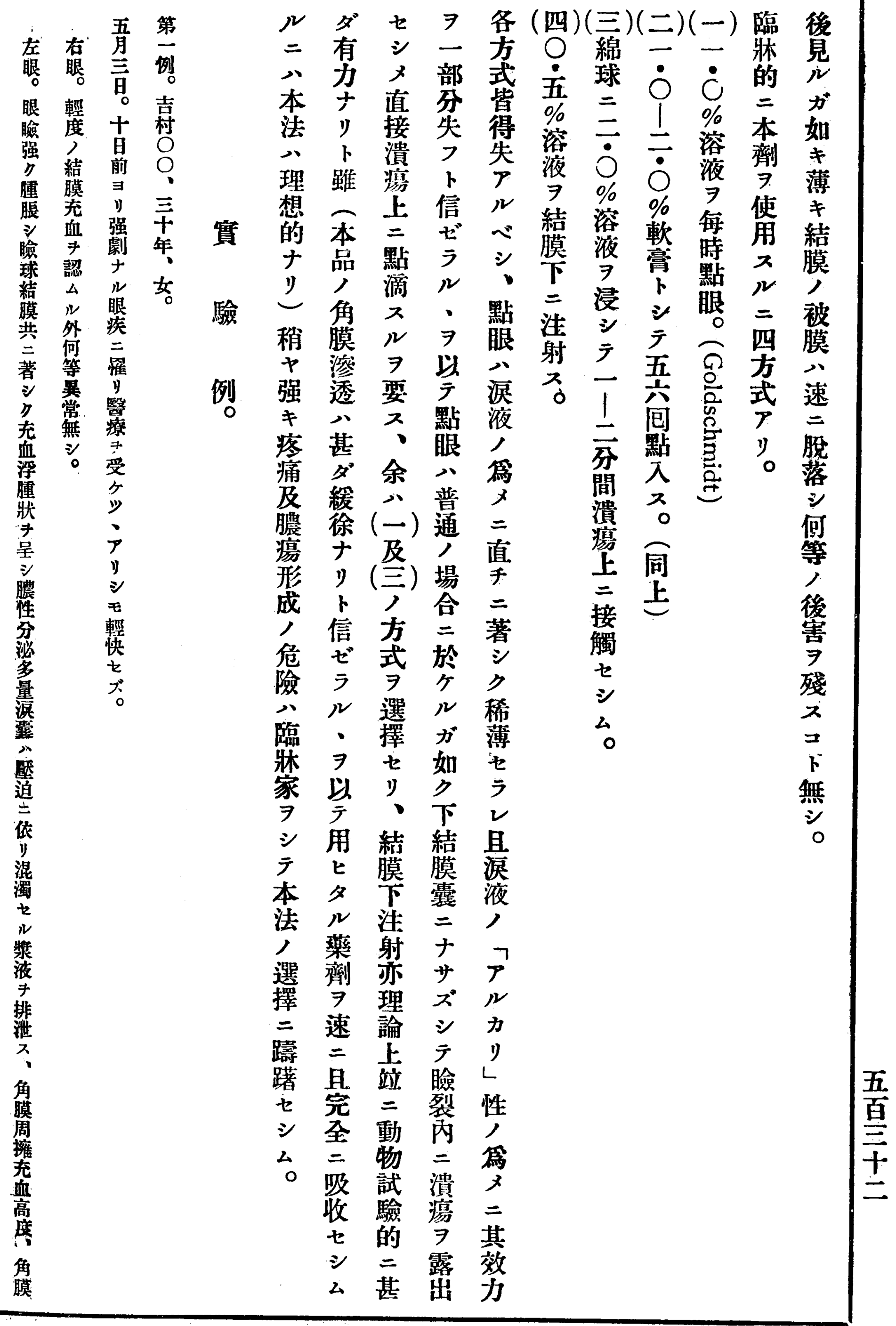




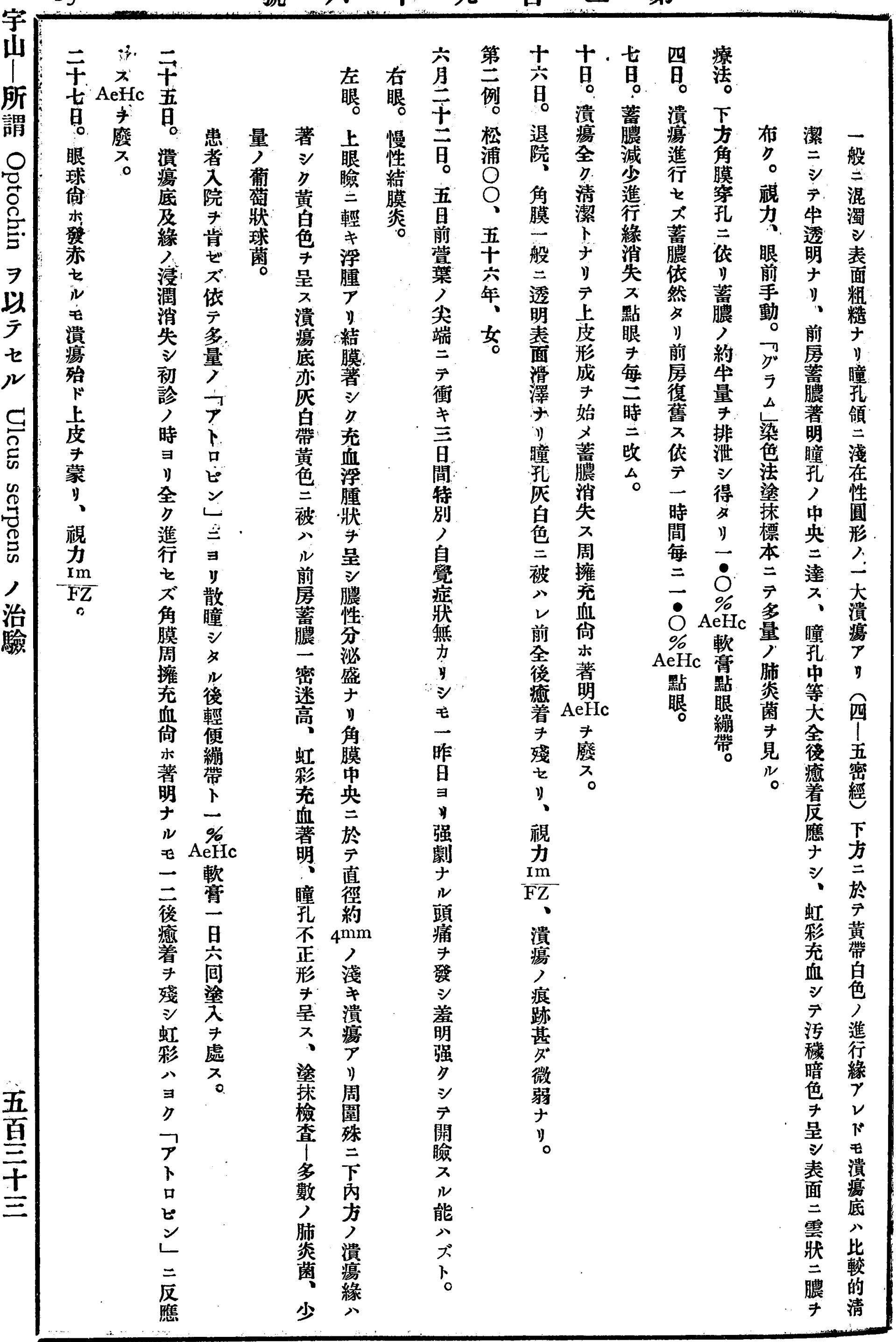




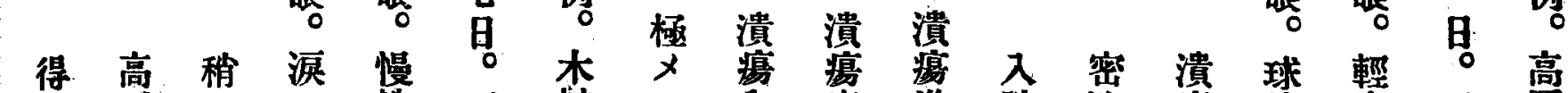

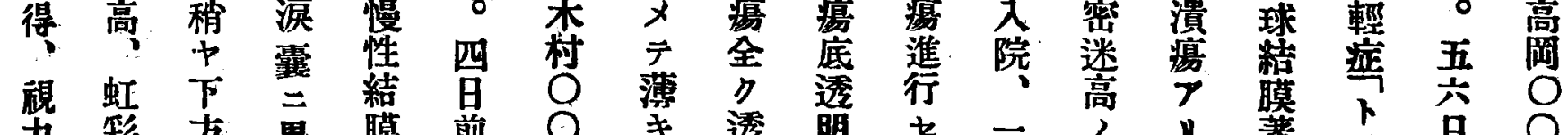
力彩方 黑莫前

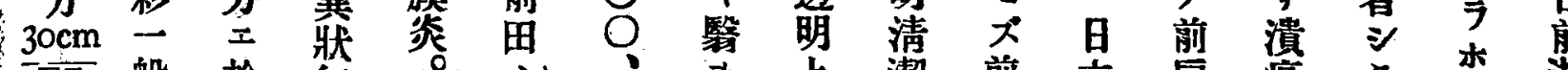
FZ 般 於 無

充 約

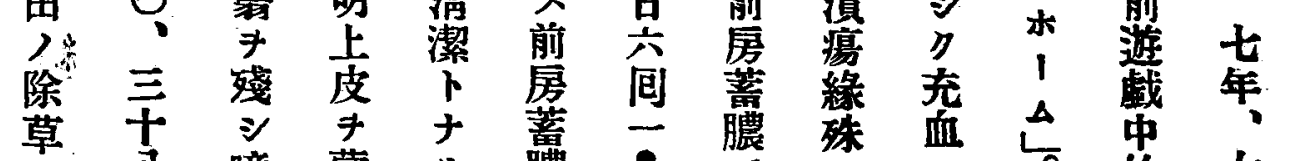

量，血 米 眼

脯濁 楢

竾

菌潰 小

$\Rightarrow$ 湯 潰 浮

證 後面䈓 腫

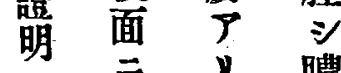

ス 相 極胜

當 女 分

ス 泌

瞳在

毛 性 結

緣 ナ膜

$=\vee$ 殊

强卜

キ 五 球

後 潰 結

癒 瘍 膜

着 線 著

》 珠 咅

》三充

此方血

* 緣 腫

草八 睡

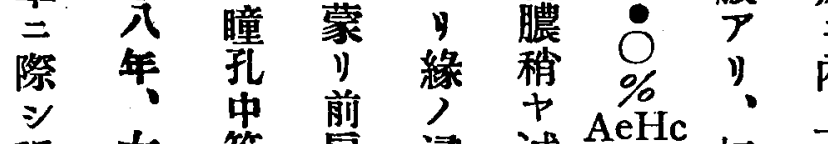

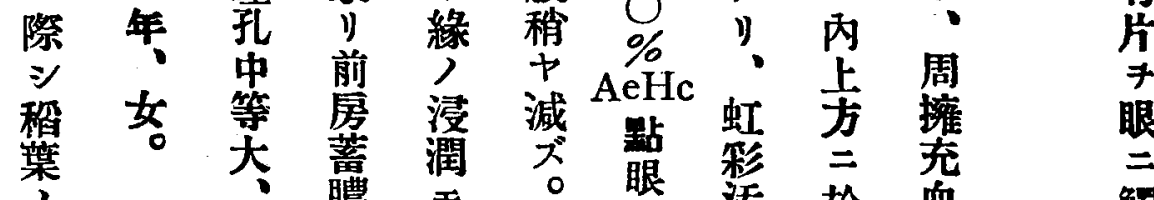

除及

多底》。

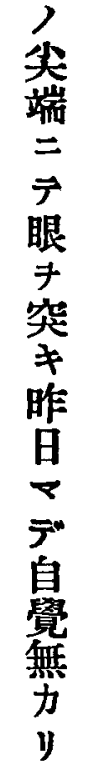

量原角

，白 膜

ᄀ色猿

卜浸。充

口潤 血

ビ シ 著

义險 明

視 無 恋

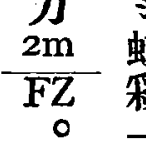

蛣酎

阝

口膿

ᄂ 是

二 $=$

稍 减

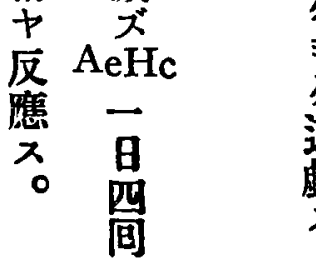

鹰

活於血

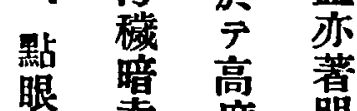

後赤度 奛

何色灰

等。曈白

㮅

卜 門

無

ガ 認 明

如 L 湍 流

口 陽等

ヨ 反㫘無

游應 三 港

中 女

二㴔角

王

ス $ス$ 亦 囊

眼

以

來

就

$\underset{\exists}{\text { 力 }}$

失

t

タ

党

如

然

v

ド

モ

政

視 灰 星

$30 \mathrm{~cm}$ 色 狀

$\mathrm{FZ}=$ 無

跳

夜

劇

4

鏡潤 角

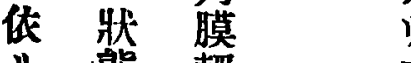

$y$ 態 輕

輕 二 度

$\eta$ 在 三

$+$

㭲

類

黄 混

脯白 濁

弥被瞪

能

膜乱

蒙暏

么 稍

N

如方

$\neq \equiv$

二於

瞳 前 濁

F

n蓄 睹

コ膿孔

₹. 約 領

淺

洁

三 


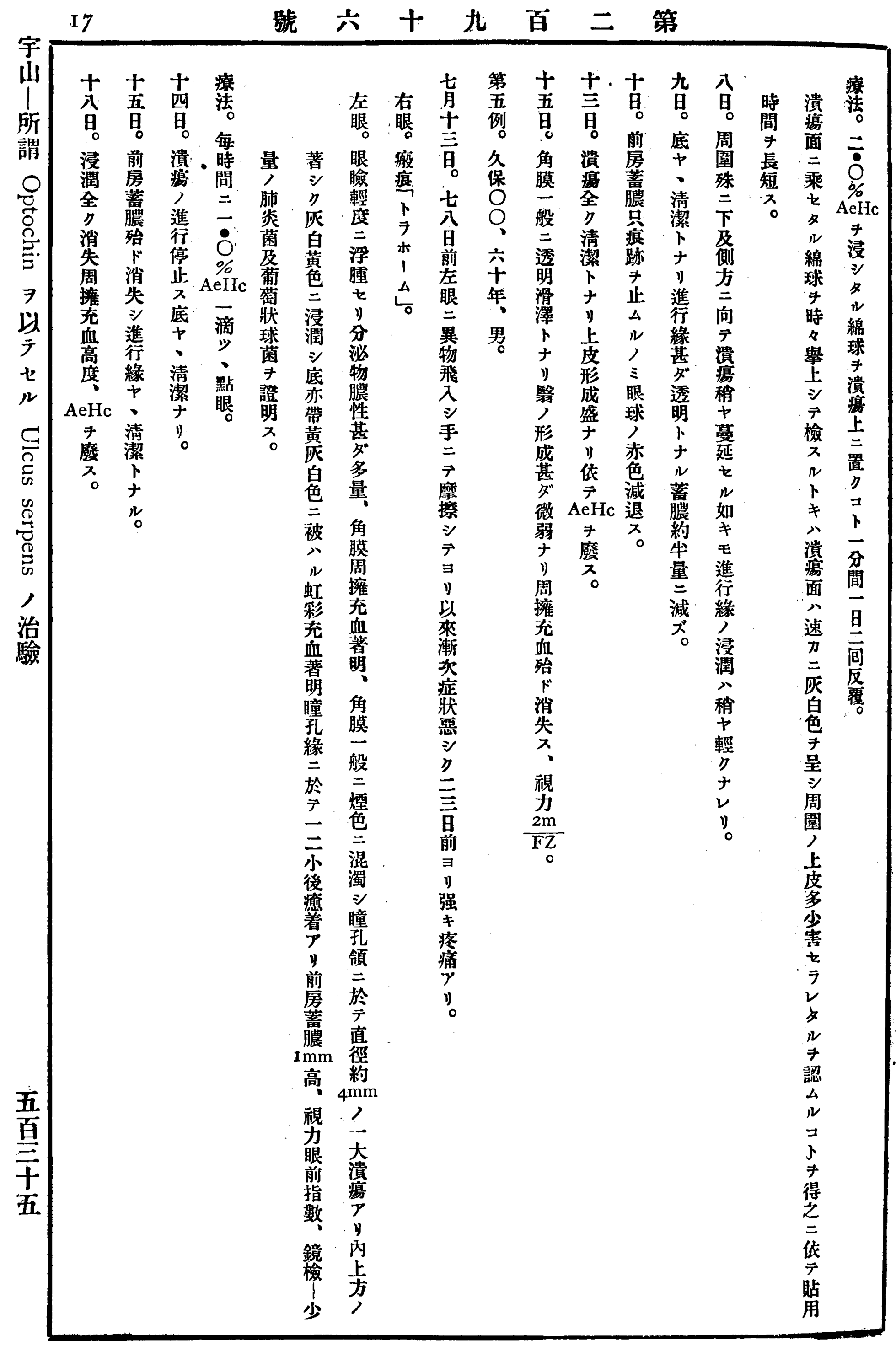




\section{號 六十九百二第}

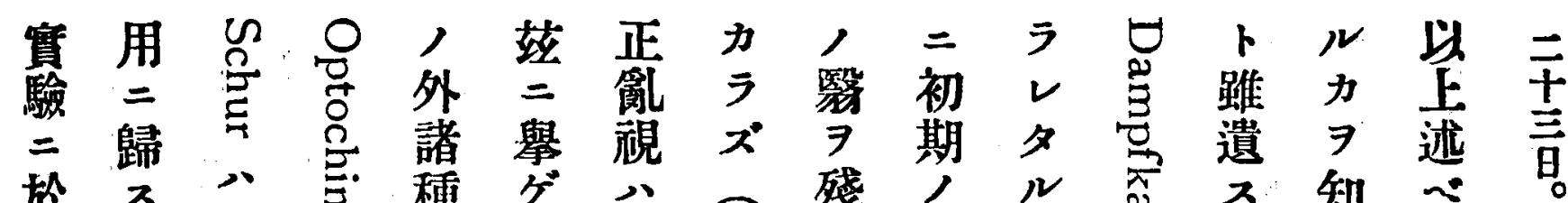
於 公斯

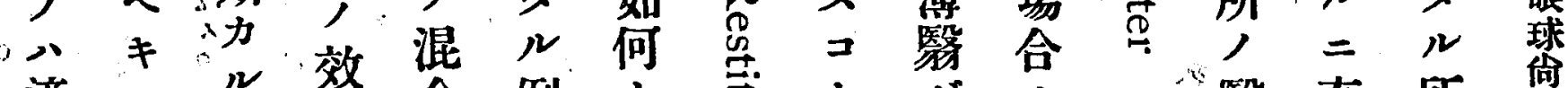

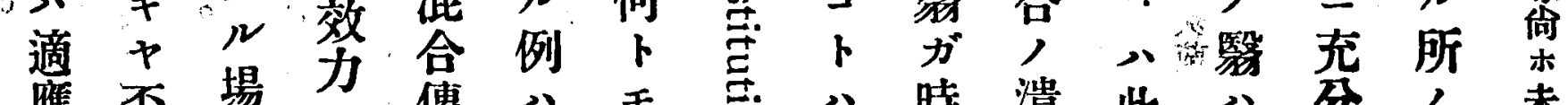

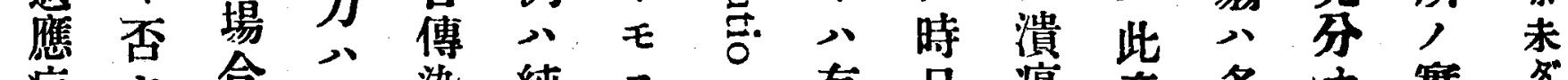

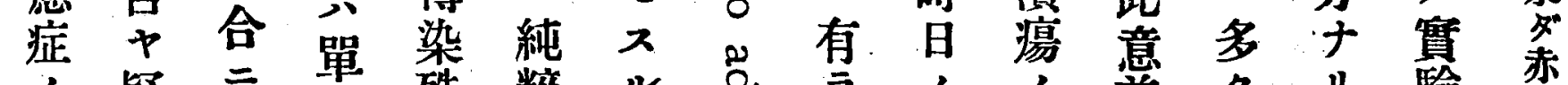

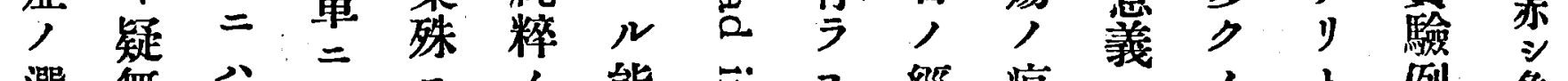

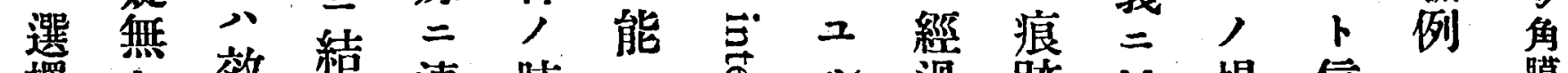
擇毛效縸連肺

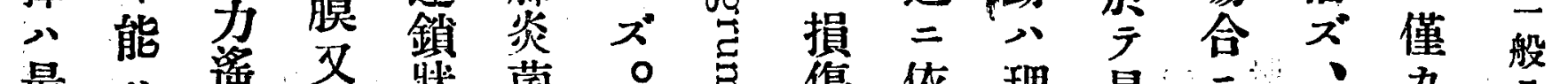

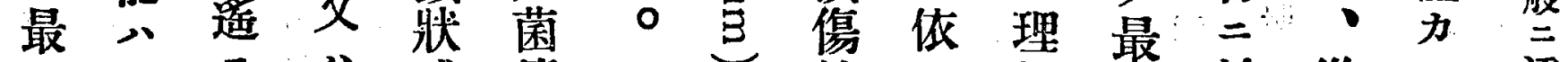
モ $ス ゙$ 二 嚴 郎劣 角菌, 染 密千り膜 傳少

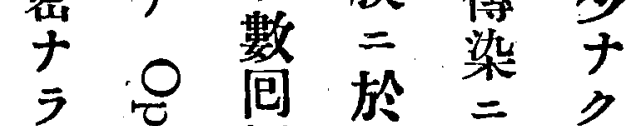
サ 总反 占 多 共 它椱副少前 へ シ 齐 副, 炎 カ) 作肺菌 今作始用炎, ズ用邓, 菌 數

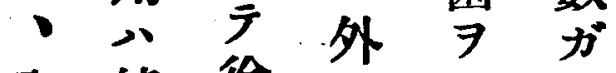
會純徐何證他

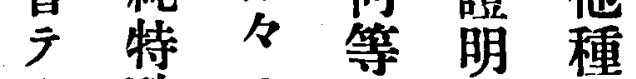
小殊三本音病。 川的停病得原 博二歨, 菌 士 シ 及 經 場 以 二 渵過合上 眼從退過合卡 科亏セ對本 實本り入劑場 地劑占年合 家, 唱影試 價 ᄀ 響 留 限 對值占量等 渎認夕》 細定之咥》、 菌公 7 、余 檢 品能此

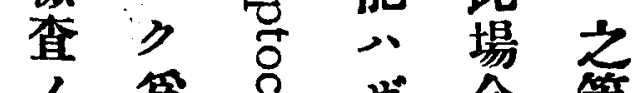

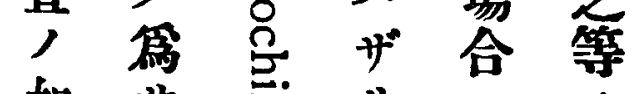

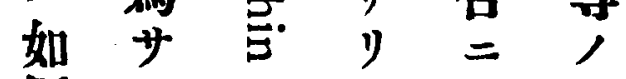
何 $ル$, 於場 相作 、合

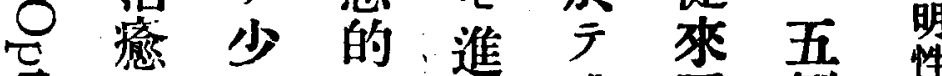

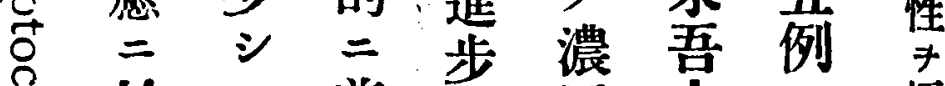
於 $€$ 善三厚人三快

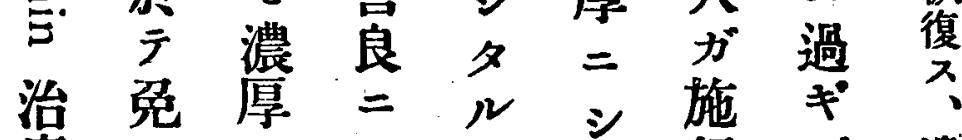

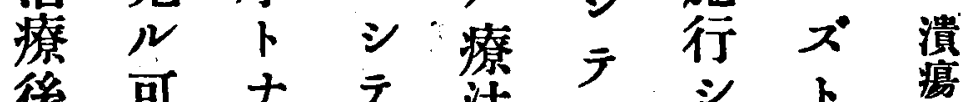

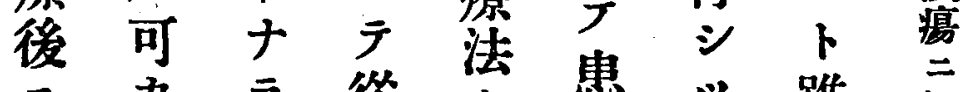
$=力 5$ 徰点患\%踓相 ケザル, 思人謂 ス $\sim ⿻ コ$ 療 $\exists$ 視 $N O$ 初

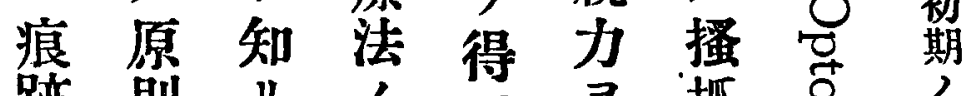

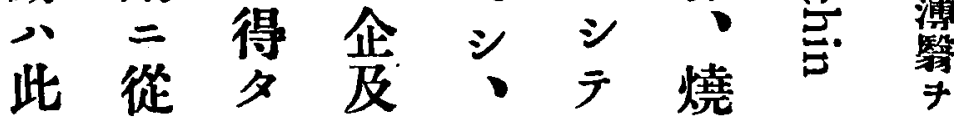

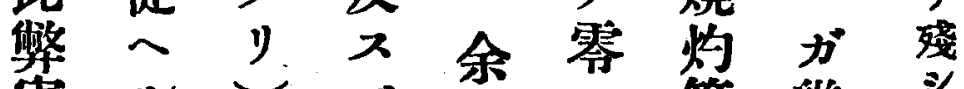
害ルさい余等幾跨

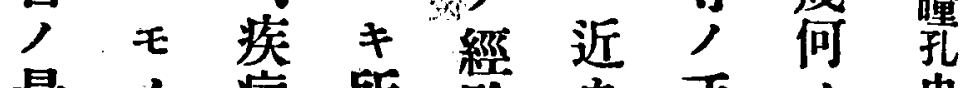
最, 病所驗务手, 虫 限儿角非使三的度 卜 $\exists$ 膜 $ス$ 公療三神 認以算会心法角

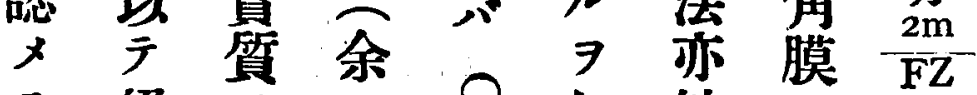
5 絕 7 只家如缺, FZ

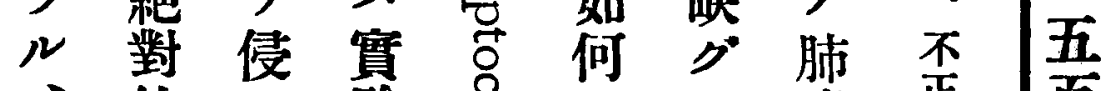

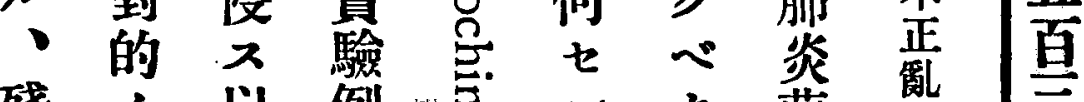

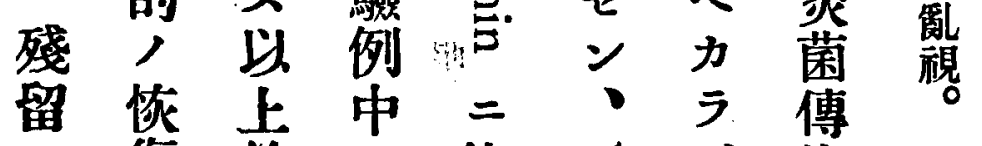

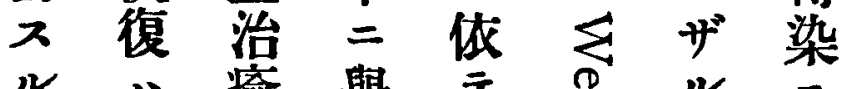

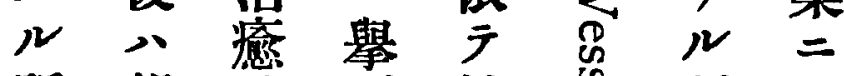
所望後多治总所有

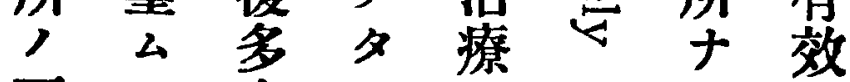

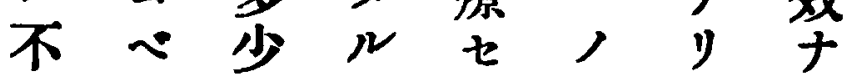




\section{此}

機訒毛著 要

會么輩 ナ

○ 就

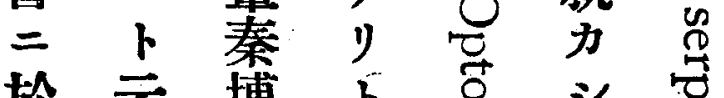

於云博 $\overrightarrow{0}$ 员 突

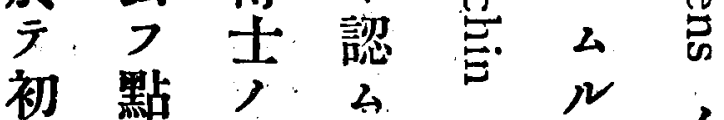

$x=$ 業引，

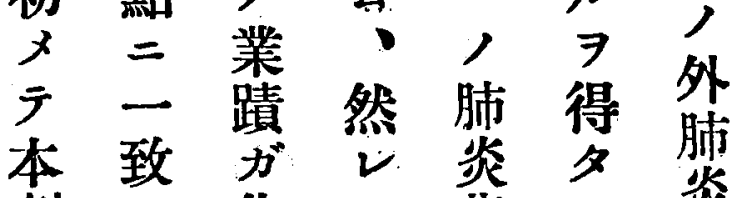

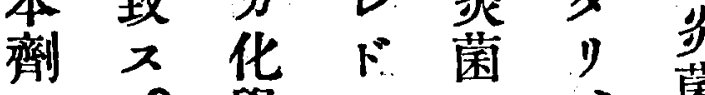

万 0 學王 對 其

手療劑入他依

二法, 心涺雨

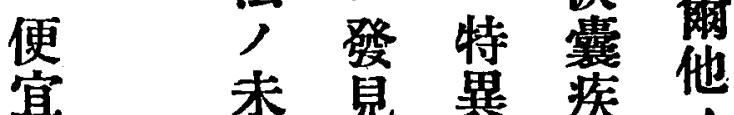

宜

與

亏

v

タ

N

大

高

等

醫

學

松

教

諭

宮

博

$\pm$

$\overline{\overline{1}}$

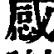

謝

占

敬

意

表

중
來 公作患

～單 用 三 眼

”一只有疾

$\overline{\bar{\gamma}}=$ 試傚

著与驗t急

哀管色急

》气 总

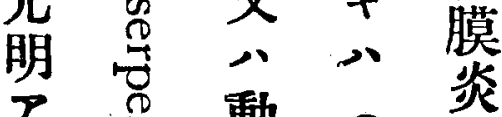

兽 動

撚物高

× 法 驗

夕上的

$\nu \equiv=\stackrel{0}{\pi} \%$

$\exists$ 證, 液

書革 驗每

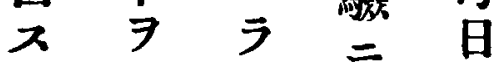

點 三夕第亥

二夕几證包

於公如筋 數

$\bar{J} 卜$ 品

硕云臨芌,

少呀 2 持

味 $=y=$

梁於 $€$ 。

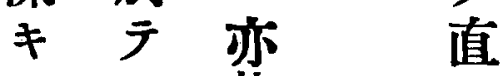

モ甚乎
光为等結

荛改明惯 $尹$

公起依兰

意點的多續
影 所 器勿 ス上療必 響人 万論 時 記 法 要 視 治ナ日實施ナ 及力療 $》 \rightarrow$ 薟行 ボガ, 然除例, カ 又他 最 $\sim \neq=$ 點 モ 療 終 ド純 徵二就 人法目 $モ$ 粹 $ᄌ$ 在 二三的之, 2 》說 非比 八习特 ズ シ 視 從 殊 本 $カ ゙$ レ 著力稀治劑今 少, 療二小 獲手分依本口 良得術十少劑卜 好又的日治, ナ八療以療應り 保法丙飞角 場存 $=$ 亏 䓨

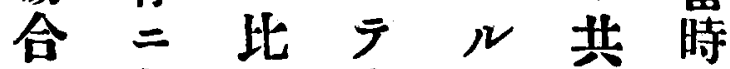
多在 又充、三特 少》 2 分 C恿 $=$ 人。゙す高基 疼疼或》恶基必 痛痛場但忽要 7 , 合 發抑筑疾要

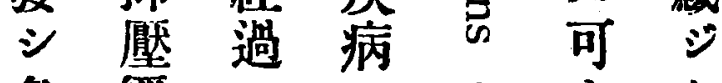
多經, , 只多 少過長消粨亏 , キ長過ザ 》

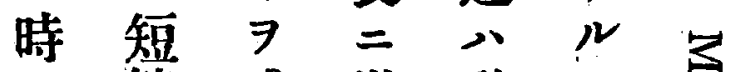
日縮感從敢 $尹$ 总 $\exists$ 亦七゙覺荠

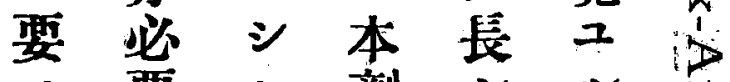

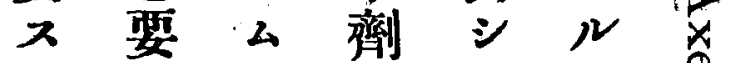

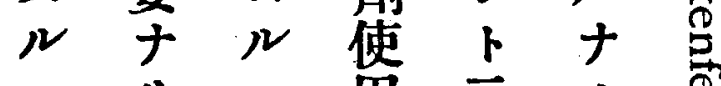

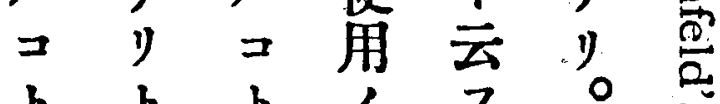
r r r, 八踓無上 本, 年三力 劑八二勘 ，枝非酩 價菜 值于然要療 $=y$, 法 何 $r=$ 等殘 $モ$ 費 tw 